\title{
TERAJU
}

Teraju: Jurnal Syariah dan Hukum

Volume 02 Nomor 02, September 2020

DOI: https://doi.org/10.35961/teraju.v2i02.164

\section{Nilai Nafkah Istri Dalam Pandangan Ulama Klasik Dan Kontemporer}

\author{
Ahmad Yani Nasution \\ Universitas Pamulang \\ dosen01583@unpam.ac.id \\ Moh Jazuli \\ Universitas Pamulang \\ dosen01680@unpam.ac.id
}

\begin{abstract}
Abstrak
Pembahasan yang menjadi fokus penelitian ini adalah tentang pendapat ulama klasik dan kontemporer tentang nilai nafkah istri. Yakni adanya perbedaan kemampuan pemberi nafkah; adanya kasus dimana seorang suami merasa telah mencukupi nafkah, namun istri merasa kurang dan menuntut lebih; adanya kasus dimana sang istri membandingkan nafkah yang diterimanya dengan nafkah yang diterima oleh tetangganya, teman-temannya, atau orang lain; adanya kasus dimana perempuan juga ikut bekerja; adanya adat atau kebiasaan yang berbeda-beda di setiap tempat; adanya perbedaan strata antara suami sang pemberi nafkah dengan istri yang menerima nafkah; terdapat seorang suami yang memberikan uang yang sangat banyak cenderung berlebihan kepada istri. Penelitian ini merupakan penelitian kepustakaan. Setelah terkumpul pendapat semua mazhab maka akan dikomparasikan antara pendapat mazhab yang satu dengan yang lainnya. Mana pendapat yang sama dan mana yang berbeda.

Kata Kunci: Nafkah istri, Ulama Klasik, Ulama Kontemporer.
\end{abstract}

\begin{abstract}
The discussion that is the focus of this research is about the opinions of classical and contemporary scholars about the value of a wife's living. Namely there are differences in the ability of providers; There is a case where a husband feels that he has enough of a living, but the wife feels less and demands more; there are cases where the wife compares the income she receives with the income received by her neighbors, friends,
\end{abstract}


or other people; there are cases where women also work; there are customs or habits that vary in each place; there is a difference in strata between the husband of the provider and the wife who receives the bread; There is a husband who gives a lot of money to his wife. This research is a library research. After the opinions of all schools have been collected, they will be compared between the opinions of one school and another. Which one is the same and which one is different Keywords: Nafkeah wife, Classical Ulama, Contemporary Ulama

\section{Pendahuluan}

Perkawinan merupakan cara yang dipilih Allah sebagai jalan bagi manusia untuk berproduksi, berkembang biak, dan melestarikan kehidupannya setelah masing-masing pasangan siap melaksanakan perannya yang positif dalam mewujudkan tujuan perkawinan ${ }^{1}$ (Abdul Rahman.2003)

Seorang istri memiliki hak untuk mendapatkan nafkah dari seorang suami, karena dengan adanya pernikahan sah isteri menjadi terikat dan menjadi milik suaminya. Sementara itu seorang isteri wajib taat kepada suami tersebut. Kewajiban suami terhadap istri ialah memenuhi kebutuhannya, memberi belanja, selama ikatan suami isteri masih berjalan, dan isteri tidak durhaka atau karena ada hal-hal lain yang menghalangi penerimaan belanja. ${ }^{2}$ (Sabiq S.tth. hlm. 229).

Selain merupakan sebuah ibadah, pernikahan atau perkawinan ini memiliki ketentuan hukum antara suami dan isteri. Pernikahan memerlukan peraturan untuk mengatur hak dan kewajiban masingmasing. Jika hak dan kewajiban masingmasing telah terpenuhi, maka dambaan suami isteri dalam bahtera rumah tangganya akan dapat terwujud, didasari

1 Abdul Rahman, Fiqh Munakahat, Cet. 1 (Jakarta: Kencana, 2003), hlm. 11.

${ }^{2}$ Sayyid Sabiq, Fiqh al-Sunnah, Juz II, (Kairo: Maktabah Dar al-Turas, tth), hlm. 229. rasa cinta dan kasih sayang ${ }^{3}$ (Rofiq A. 1997).

Allah menegaskan dalam Qs. al-Nisa ayat 19 :

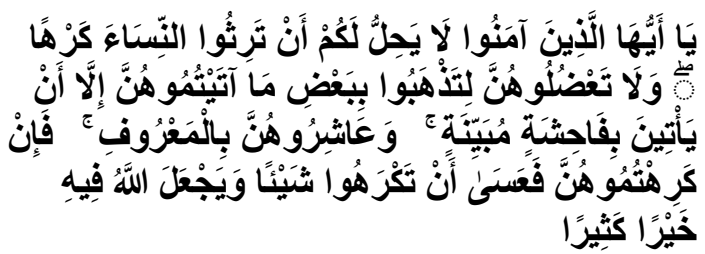

Artinya: "Hai orang-orang yang beriman, tidak halal bagi kamu mempusakai wanita dengan jalan paksa dan janganlah kamu menyusahkan mereka karena hendak mengambil kembali sebagian dari apa yang telah kamu berikan kepadanya, terkecuali bila mereka melakukan pekerjaan keji yang nyata dan pergaulilah mereka secara patut. Kemudian bila kamu tidak menyukai mereka, karena mungkin kamu tidak menyukai sesuatu, padahal Allah menjadikan padanya kebaikan yang banyak". (Qs. al-Nisa: 19). ${ }^{4}($ Depag RI. 1993).

Di dalam ayat tersebut terdapat petunjuk agar suami dan isteri dapat bergaul secara makruf (baik). Baik dari aspek fisik, psikis atau perasaan, dan ekonomi. Nafkah begitu penting dalam berumah tangga, tidak jarang dalam sebuah rumah tangga terjadi pertengkaran

\footnotetext{
3 Ahmad Rofiq, Hukum Islam di Indonesia, (Jakarta: PT. Raja Grafindo Persada, 1997) hlm. 181

4 Depag RI, Al-Qur'an dan Terjemahnya, (Surabaya: Surya Cipta Aksara, 1993), hlm. 119.
} 
bahkan perceraian akibat adanya ketidakadilan maupun rasa ketidakpuasan antar pasangan. Oleh karena itu sebagai muslim yang ingin membentuk keluarga sakinah, awaddah, warahmah haruslah memperhatikan betul esensi nafkah ini. Bahkan apabila perceraian terjadi, semua nafkah maupun pemberian suami tersebut tidaklah boleh untuk diambil kembali. Petunjuk tersebut dijelaskan dalam firman Allah dalam al-qur'an surat An-Nisa ayat 20:

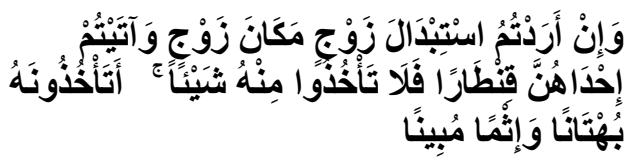

Artinya: "Dan jika kamu ingin mengganti istrimu dengan istri yang lain, sedang kamu telah memberikan kepada seseorang di antara mereka harta yang banyak, maka janganlah kamu mengambil kembali dari padanya barang sedikit pun. Apakah kamu akan mengambilnya kembali dengan jalan tuduhan yang dusta dan dengan dosa yang nyata?" ( Depag RI, Al-Qur'an dan Terjemahnya, Surabaya: Surya Cipta Aksara, 1993, hlm. 119)

Rasulullah SAW memberikan kabar gembira kepada para suami bahwasannya memberikan nafkah istri akan mendapatkan pahala. Di dala riwayah Al-Bukhari disebutkan:

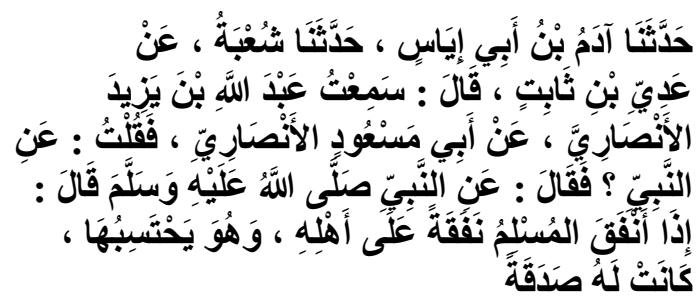

Artinya: "Adam bin Abi Iyas telah mengabarkan kepada kami dari Syu "bah dari Adi bin Tsabit berkata: Saya telah mendengar bahwa Abdullah bin Yazid alAnsari dari Abu Maseud al-Ansari ra., berkata: bahwa Rasulullah Saw. bersabda: "Apabila seorang muslim memberikan nafkah kepada keluarganya semata-mata karena mematuhi Allah, maka ia mendapat pahala". (Al-Imam Abu Abdillah Muhammad ibn Ismail ibn al-Mugirah ibn Bardizbah al-Bukhari, Shahih al-Bukhari, Juz III, Beirut: Dar al-Fikr, 1410 H/1990 M, hlm. 305).

Adapun mengenai nilai nafkah alqur'an dan hadis tidak menyebutkan dengan tegas kadar atau jumlah nafkah, baik minimal atau maksimal. Jumlah nafkah yang diberikan hendaklah sedemikian rupa sehingga tidak memberatkan suami, apalagi menimbulkan mudarat baginya, bahkan ada yang berpendapat bahwa jumlah nafkah itu juga harus disesuaikan dengan kedudukan isteri $^{5}$ (Daradjat Z.1995). Dalam al-qur'an surat al-Thalaq ayat 6-7 dijelaskan:

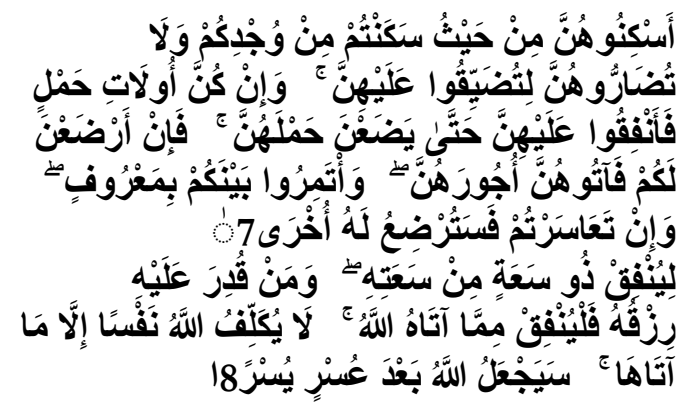

Artinya: "Tempatkanlah mereka di mana kamu bertempat tinggal menurut kemampuanmu dan janganlah kamu menyusahkan mereka untuk menyempitkan mereka. Dan jika mereka itu sedang hamil, maka berikanlah kepada mereka nafkahnya hingga mereka bersalin, kemudian jika mereka menyusukan mu untukmu maka berikanlahkepada mereka upahnya, dan musyawarahkanlah di antara kamu dengan baik; dan jika kamu menemui kesulitan maka perempuan lain

5 Zakiah Daradjat, Ilmu Fiqih, jilid II, (Yogyakarta: PT.Dana Bhakti Waqaf, 1995), hlm. 145. 
boleh menyusukan untuknya. Hendaklah orang yang mampu memberi nafkah menurut kemampuannya. Dan orang yang disempitkan rezkinya hendaklah memberi nafkah dari harta yang diberikan Allah kepadanya. Allah tidak memikulkan beban kepada seseorang melainkan sekedar apa yang Allah berikan kepadanya. Allah kelak akan memberikan kelapangan sesudah kesempitan ${ }^{6}$ (Depag RI.hlm. 946).

Kalangan ulama klasik (Hanafiyah, Malikiyah, Hanabilah, maupun Syafi'iyah terdapat sedikit perbedaan pendapat mengenai nilai nafkah, mulai dari kriteria maupun ukurannya. Adapun di kalangan ulama kontemporer (Dr Yusuf Qardhawi dan Wahbah Azzuhaily) masih mengikuti pendapat ulama klasik, namun terjadi perluasan tentang penjabaran nilai nafkah karena adanya perubahan zaman dan kebutuhan hidup.

Berbagai masalah yang timbul tentang nilai nafkah dalam kehidupan sehari-hari ini sering menimbulkan pertanyaan seperti apa sebenarnya nilai nafkah tersebut. Berikut berbagai permasalahan yang penulis dapatkan dalam kehidupan sehari-hari. Yakni adanya perbedaan kemampuan pemberi nafkah; adanya kasus dimana seorang suami merasa telah mencukupi nafkah, namun istri merasa kurang dan menuntut lebih; adanya kasus dimana sang istri membandingkan nafkah yang diterimanya dengan nafkah yang diterima oleh tetangganya, teman-temannya, atau orang lain; adanya kasus dimana perempuan juga ikut bekerja; adanya adat atau kebiasaan yang berbeda-beda di setiap tempat; adanya perbedaan strata (kaya/miskin) antara suami sang pemberi nafkah dengan istri yang menerima nafkah; terdapat seorang suami yang memberikan uang yang sangat banyak cenderung berlebihan

6 Depag RI, Al-Qurean, Al-Qur'an dan Terjemahnya, op.cit., hlm. 946 kepada istri sehingga seolah-oleh tidak mengingat adanya hari esok; sebaliknya terdapat pula seorang suami yang terlalu pelit terhadap istri.

Adanya permasalahan-permasalahan tersebut mendorong penulis untuk melakukan penelitian mengenai nilai nafkah ini. Penulis berharap dengan mengembalikan pada al-quran, sunnah, serta pendapat ulama baik yang klasik maupun kontemporer dapat membantu penulis secara khusus dan keluarga muslim umumnya untuk mengetahui gambaran tentang nilai nafkah ini.

Berdasarkan latar belakang yang telah dipaparkan sebelumnya maka dapat dirumuskan pokok masalah dalam penelitian ini ialah: Bagaimana pendapat ulama klasik mengenai nilai nafkah istri dan bagaimana pendapat ulama kontemporer mengenai nilai nafkah istri serta bagaimana perbandingan ukuran nafkah menurut ulama klasik dan kontemporer.

Jenis penelitian ini merupakan penelitian kepustakaan/ library research, yang menggunkan sumber data berupa literatur baik primer, sekunder, maupun sumber pendukung. Data yang didapatkan kemudian dikumpulkan dan diteliti. Setelah itu dilakukan analisis perbandingan pendapat ulama klasik dan ulama kontemporer; dengan analisis figh perbandingan atau fiqh muqaranah. Dari hasil perbandingan tersebut dilakukan pentarjihan untuk menghasilkan sebuah kesimpulan.

Penulis menggunakan kitab-kitab fiqih dari ulama empat madzhab sebagai Sumber data sekunder. kemudian ada bebearapa kitab tafsir diantaranya adalah at-Tahbari, Ibnu Katsir dan lainya. dan kitab-kitab hadits terjemah yang termasuk dalam kutub al- Sittah seperti shahih Bukhari yang di-syarah-kan oleh Ibnu Rojab al-Atsqalany, Sunan Ibnu Majah, 
Shahih Muslim dengan syarah al-Nawawiy, Sunan Abu Daud, sunan al-Nasa'i dan Sunan al-Turmudzi. Selain dari itu ada beberapa kitab hadist lainnya seperti Subulussalam karya al-Shan'aniy, Nail alAthar Karya al-Syaukaniy. Dan yang lebih penting semua kitab yang berkaitan dengan fiqih 4 Madzhab. Selebihnya tulisan yang yang menurut penulis ada kaitannya dengan penelitian ini.

\section{Pembahasan}

A. Nilai nafkah istri menurut ulama klasik

1. Hanafiyah

Jika kondisi suami dan istri sama (kaya keduanya/miskin keduanya), ulama hanfiyah sepakat diukur sesuai kondisi tersebut. Namun jika diantara suami dan istri tersebut terdapat perbedaan kondisi (istri kaya dengan suami miskin / suami kaya dengan istri miskin) maka terdapat dua pendapat. Pertama, nafkah yang diberikan dengan ukuran pertengahan dan pendapat kedua mengikuti kondisi suami. Maksud dari pendapat kedua tersebut, jika suami kaya istri miskin maka nafkah yang diberikan haruslah nafkah dengan kelapangan; sedangkan jika suami miskin istri kaya maka nafkah yang diberikan suami semampu suami.

Golongan Hanafiyah juga berpendapat bahwa agama tidak menentukan jumlah nafkah. Suami wajib memberi nafkah kepada istrinya dengan cukup meliputi makanan, daging, sayur-mayur, buah-buahan, minyak zaitun dan samin serta segala kebutuhan yang diperlukan dalam hidupnya sehari-hari dan sesuai dengan kebiasaan umum. Standar ini berbeda menurut keadaan dan situasi

7 Al-Juzairi. Fikih 4 mazhab. Jilid 4, (Maktabah Taufikiyah Kairo, tt). Hal 536. tempat. Suami pun wajib memberikan pakaian musim dingin dan panas kepadanya. Abu Hanifah sendiri lebih cenderung melihat ukuran nafkah berdasarkan kondisi suami saja. Abu Hanifah berpendapat bahwa istri wajib diberikan nafkah oleh suami sebesar tujuh sampai delapan dirham setiap bulan, sedang orang yang pendapatannya kecil wajib memberikan nafkah dibawah tujuh dirham yaitu empat sampai lima dirham ${ }^{8}$. Menurut Imam Abu Hanifah dan Imam Malik yang mengatakan bahwa yang dijadikan standar adalah kebutuhan istri. ${ }^{9}$

Adapun yang menjadi dasar bagi ulama ini adalah firman Allah dalam Al-Qur'an Surat Al-Baqarah ayat 233 yang artinya "Kewajiban suami menanggung biaya hidup dan pakaian yang patut."

Di kalangan hanafiyah nilai nafkah penentuannya diwakilkan oleh Qadhi (hakim) yaitu dengan memperhatikan kondisi ekonomi suami atau kondisi suami istri. ${ }^{10}$ Kemudian seorang Qadhi harus mempertimbangkan mana yang lebih maslahat antara biji-bijian (makanan pokok) atau yang senilai dalam bentuk uang. Jika yang terbaik adalah biji-bijian sebagai makanan pokok maka diberilah nafkah biji-bijian. Sebaliknya jika uang yang lebih baik maka uang yang diberikan. Uang yang diberikan kepada istri sesuai dengan harga makanan pokok yang berlaku, dan sangat tidak dianjurkan

8 Yusuf Qarḍhawi, Fatwa-Fatwa Kontemporer, Jilid 1, Terjemah, As'ad Yasin, Jakarta: Gema Insani Press, 2008), hlm. 679.

9 Amir Syarifuddin, Hukum Islam di Indonesia, Cet. 2 (Jakarta: Kencana, 2007), hal. 170.

10 Ibid. Hal 357. 
dalam bentuk uang karena bisa jadi harga dapat berubah sesuai masanya.

Pemberian nafkah ini bisa per hari, per minggu dan per bulan. Jika suami bekerja sebagai karyawan yang mendapatkan gaji perbulan maka ia wajib memberi nafkah istrinya perbulan. Jika suami seorang karyawan yang mendapatkan gaji per minggu wajib nafkah per minggu, dan jika suami seorang suami seorang petani yang panen sekali setahun maka nafkah diberikan sekali setahun untuk belanja setahun.

2. Malikiyah

Ulama Malikiyah memiliki dua pendapat. Pertama, jika suami istri sama-sama kaya atau sama sama miskin maka nafkah sesuai kondisi. Kedua, jika keduanya berbeda suami kaya istri miksin atau sebaliknya maka diberikan nafkah pertengahan.

Malikiyah memberikan kebebasan kepada suami dalam memberikan nafkah istri sebagaimana pada keterangan diatas. Jika atas kemauan istri maka suami boleh memberikan nafkah senilai harga yang berlaku didaerah tersebut namun jika tidak maka dengan memberikan sesuai haknya dan sesuai kemampuan seorang suami. Jika ia seorang karyawan bulanan maka setiap bulan suami harus memberikan nafkah. Begitu juga kalau bulanan maka setiap bulannya, dan jika tahunan maka setiap tahunnya untuk belanja setahun.

3. Hanabilah

Hanabilah berpendapat seperti perndapat hanafiyah yaitu nafkah diukur berdasarkan kondisi lapang dan sulitnya suami istri secara bersamaan. Adapun jika terjadi perbedaan kondisi yaitu suami kaya dan istri miskin begitu juga sebaliknya maka ukuran nafkah yang harus diberikan suami yaitu nafkah pertengahan.

Tidak ada keharusan apakah nafkah yang diberikan harus dengan makanan pokok atau uang yang senilai dengan bahan pokok tersebut, kecuali atas kesepekatan bersama. ${ }^{11}$

4. Syafi'iyah

Ulama syafi'iyah berpendapat bahwa ukuran makan dan pakaian istri itu tergantung kondisi suami. Artinya jika suami kaya maka makan dan pakaian istri haruslah standar bagus, namun jika suami tersebut fakir maka standarnya rendah. Sementara nafkah tempat tinggal harus yang patut meskipun kondisi suami tersebut fakir. Karena tempat tinggal bisa disewa tanpa harus memiliki. ${ }^{12}$

Ulama syafi'iyah juga mengukur nafkah istri itu dengan beberapa bagian yaitu makan, pakaian, dan tempat tinggal. Nafkah tersebut tidak boleh diuangkan dan tidak wajib mengambil uang seharga nafkah tersebut. Adapun makan sehari-hari maka boleh mengambil juga harga nafkah untuk besok.

Nafkah makanan tersebut diberikan adalah biji-bijian beserta lauknya. Adapun yang dimaksud dengan biji-bijian adalah makan pokok setempat. Yaitu gandum, jagung, atau beras. Kemudian yang dimaksud dengan lauknya adalah lauk yang biasa dikonsumsi di tempat tersebut seperti daging, minyak, madu. Hal seperti ini diwajibkan bagi seorang suami yang kaya sebanyak 2 ritlun daging, 1,5 ritl bagi yang sedang

\footnotetext{
${ }^{11}$ Ibid 537

12 Ibid. Hal 536.
} 
dan 1 ritl bagi suami yang faqir setiap jumat. ${ }^{13}$

Ulama Syafi'iah ${ }^{14}$ berpendapat yaitu dengan takaran yang sudah ditentukan. Namun demikian ukurannya akan dilihat dari kemampuan seorang suami. Jika seorang suami dalam kondisi mudah maka wajib memberikan 2 mud (1.350 gram gandum/beras), jika dalam kondisi sulit 1 mud (1012,5 gram) dan jika dalam kondisi stabil yaitu antara kondisi mudah dan sulit maka wajib memberikan nafkah istri sebanyak 1,5 mud $(675 \text { gram })^{15}$. Jika dipaksa membayar 2 mud setiap hari, dia akan jatuh miskin. Sebaliknya jika hanya membayar satu mud setiap hari maka hal itu akan membahayakan pihak istri karena hak-hak istri kurang diperhatikan. Dengan demikian, maka dia berkewajiban mengeluarkan nafkah 1,5 mud setiap hari. Namun, semua itu harus tetap mengacu pada kebiasaan dan tradisi. ${ }^{16}$

Menurut Imam Syafi'i dan pengikutnya berpendapat bahwa sebab terjadinya nafkah ada tiga, yaitu: kekerabatan, kepemilikan (perbudakan), dan perkawinan. Nafkah seorang istri wajib atas suaminya. Namun, nafkah tersebut berbeda sesuai dengan keadaan atau kemamapuan suami. Syafi'i mengatakan, "Yang dimaksud nafkah di sini ada dua macam, yaitu nafkah

13 Jasir Judah 'Ali Al”Asy, Nafaqoh Jauziyah, (Gaza: Kulliyah Syari’ah Wal Qanun, 2007), Hal. 90-91

14 Taqiyuddin, Kifayat Al-Akhyar, (Damaskus : Daar Al-Basyair, tt), hal. 526

${ }_{15}$ Al-Imam Abi Abdullah Muhammad bin Idris al-Syafi'i, Al-Umm, Juz V, (Beirut: Dar al-Kutub al-Ilmiyah, tt), hlm. 95

16 Wahbah Zuhaili, Fiqh Imam Syafi'i, Jilid 3,Terj. Muhammad Afifi, abdul Hafiz (Jakarta: Almahira, 2010), hal. 43. orang yang dalam keadaan miskin dan nafkah orang dalam keadaan kaya. Bagi yang miskin, maka ia cukup memberikan satu mud makanan pokok yang berlaku pada Negeri tempat ia hidup kepada pembantunya. Dan cukup pada setiap pekannya memberikan satu kerat daging. Selain itu, ia juga berkewajiban memberi pakaian yang layak dan wajar di lingkungannya. Begitu juga halnya jika suaminya itu seorang yang berada, maka ia berkewajiban memberi istrinya dua mud. Juga lauk pauk dan daging yang jumlahnya dua kali lipat yang diberikan oleh suami yang hidup miskin. ${ }^{17}$

B. Dalil-Dalil Nilai Nafkah Istri Menurut Ulama Klasik

Jumhur ulama menggunakan dalil naqli dan aqli sebagi berikut:

Naqli adanya QS. Al-Baqoroh ayat 233 dan hadis:

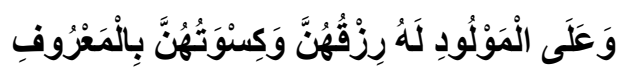

Artinya: "Dan kewajiban ayah memberi makan dan pakaian kepada para ibu dengan cara ma'ruf."

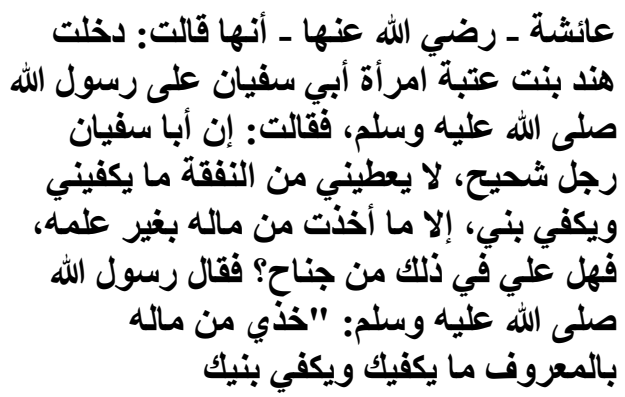

Artinya : dari Aisyah(5), bahwa Hindun bin Utbah istri Abi Sufyan pernah berkata kepada Rasulullah;

${ }^{17}$ Syaikh Hasan Ayyub, Fikih Kelurga, Terj. M. Abdul Ghoffar, (Jakarta Timur: Pustaka Al-Kausar, 1999), hlm. 384. 
"Sesungguhnya Abu Sufyan adalah seorang lelaki yang kikir, dia tidak memberiku dan anakku sesuatu yang mencukupi kami kecuali apa yang aku ambil dari hartanya tanpa sepengetahuannya!." Apakah saya termasuk orang yang berdosa? Kemudian Beliau bersabda: "Ambillah secukupnya untuk kamu dan anakmu dengan cara yang baik.

'Aqli: Sesungguhnya nafkah batihiniyah merupakan kewajiban bagi suami untuk memenuhinya begitu juga nafkah lahiriah secukupnya.

Menurut Imam Hanafi dan Imam Malik yang mengatakan bahwa yang dijadikan standar adalah kebutuhan istri. Hal ini berdasarkan firman Allah dalam Al-qur'an Surah Al-Baqarah ayat 233. Kalangan Hanafi menetapakan jumlah nafkah istri sesuai dengan kemampuan suami, baik kaya atau miskin, tanpa melihat keadaan istrinya. Seperti Firman Allah dalam Q.S. Ath-Thalaq ayat 6-7. ${ }^{18}$

Menurut Imam Hanafi, Maliki, dan Hambali bahwa mengqiyaskan nafkah zahiriyah pada kafarat tentang kadar nafkahnya tidak diterima, karena nafkah ditetapkan tidak sama dengan kafarat. Kafarat sama banyaknya bagi orang kaya dan miskin, di dalam kafarat tidak memberikan lauk pauk, hanya beras dan gandum saja, sedangkan pada nafkah wajib memberikan lauk pauk dan dalam kafarat disyaratkan untuk mencukupi istrinya. ${ }^{19}$ Batasan orang yang berkehidupan mudah (kaya), sulit (miskin), atau cukup (menengah) berdasarkan kebiasaan yang berlaku

18 Sayyid Sabiq, Fiqih Sunnah, Terj. Nor Hasanuddin, jlid 3, (Jakarta Selatan: Pena Pundi Aksara, 2006), hlm. 62.

${ }^{19}$ Mahmud Yunus, Hukum Perkawinan Dalam Islam, (Jakarta: CV. Al-Hidayah, 1968), hlm. 104. ditengah masyarakat. Kebiasaan ini dapat berubah-ubah tergantung pada waktu, tempat, dan keadaan. ${ }^{20}$

Ulama Syafie iyyah berpendapat bahwa nafkah makanan itu dapat ditimbang atau kira-kirakan dengan biji-bijian sesuai dengan keadaan ekonomi masing-masing. Karena, minimal denda kafarat yang dikeluarkan seseorang adalah satu mud biji-bijian. Allah SWT menganggap kafarat itu untuk keluarga, sebagaimana dalam FirmanNya:

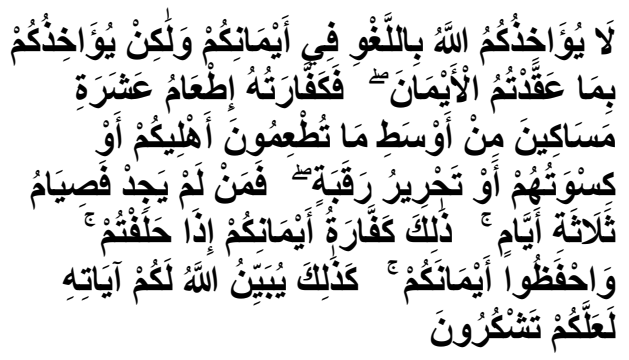

Artinya: "Allah tidak menghukum kamu disebabkan sumpah-sumpahmu yang tidak sengaja (untuk bersumpah), tetapi dia menghukum kamu disebabkan sumpah-sumpah yang kamu sengaja, maka kafaratnya (denda pelanggaran sumpah), ialah memberi makan sepuluh orang miskin, yaitu dari makanan yang biasa kamu berikan kepada kelurgamu, atau memberi mereka pakaian atau memerdekakan seorang hamba sahaya. Barang siapa tidak mampu melakukannya, maka (kafaratnya) berpuasalah tiga hari. Itulah kafarat sumpah-sumpahmu apabila kamu bersumpah. Demikianlah Allah menerangkan hukumhukum-Nya

20 Al-Qahdi Abu Syujae Bin Ahmad AlIshfahani, Ringkasan Fiqih Mazhab Syafi ${ }^{\text {ee }}$ Penjelasan Kitab Matan Abu Syujae Dengan Dalil Al-Quran Dan Hadits, Terj. Toto Edidarmo, (Jakarta: Noura Books, 2012), hlm. 509. 
kepadamu agar kamu bersyukur (kepada-Nya). (Q.S AlMaidah:89).

Persamaan nafkah dan kafarat dalam ayat di atas karenanya sama-sama harta yang wajib dikeluarkan syara ${ }^{\text {ee }}$ Suami yang kaya nafkah makanan untuk istrinya dua mud perhari, sedangkan suami yang miskin nafkah bagi istrinya hanya satu mud, dan suami yang sedang nafkahnya satu mud setengah. Perbedaan ini diambil dari firman Allah SWT surah Aththalaq ayat 7. Adapun maksimal kafarat wajib yang harus dikeluarkan adalah dua mud tiap orang miskin, yaitu sama dengan kafarat adza sebab memotong rambut dan kuku dalam pelaksanaan ibadah haji. Minimal harta yang harus dikeluarkan adalah satu mud dalam kasus seperti kafarat zhihar. Karena itu, ulama Syafie yyah mewajibkan untuk orang kaya dua mud dan satu mud untuk orang miskin, dan untuk orang ekonomi sedang satu setengah mud. ${ }^{21}$

Adapun dalil Naqlinya ialah QS. At-talak ayat 7 dan hadist sebagai berikut:

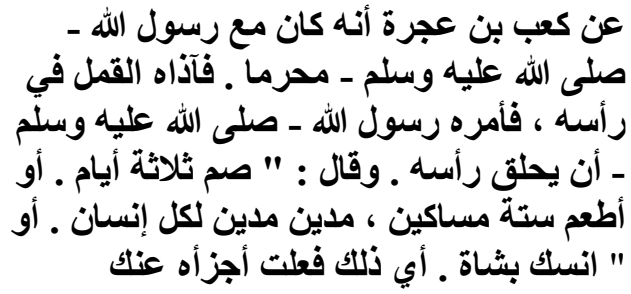

Dari Ka'b bin Ajrah ra. Bahwasanya dia bersama Rasulullah SAW. Dia memukul Kutu rambut yang mengenai kepalanya, jadi Rasulullah SAW memerintahkannya untuk mencukur rambutnya. Dan dia berkata: "Berpuasa selama tiga hari. Atau beri makan enam orang miskin,

${ }^{21}$ Wahbah Zuhaili, Fiqh Islam Wa..., hlm. 121. seorang yang berutang berutang pada setiap orang. Atau memelihara seekor domba. Artinya, aku melakukan itu akan cukup untukmu."

Sedangkan dalil aqlinya ialah: "sesungguhnya rasulullah selalu memerintahkan para sahabat yang melanggar aturan haji dengan fidyah yaitu wajib memberi makan orang miskin. Dengan demikian secara otomatis orang tersebut berhutang kepada orang miskin." Begitu juga kewajiban lainnya syafi'iyah menyamakannya dengan kaffaroh termasuk kewajiban kepada istri.

C. Nilai Nafkah Istri Menurut Ulama Kontemporer

Tidak ada jumlah tertentu untuk kadar nafkah bagi keluarga. Ini kembali kaepada kondisi masingmasing dan adat kebiasaan yang berlaku pada satu masyarakat atau apa yang diistilahkan oleh Al-Qur'an dan Sunnah dengan „urf yang tentu saja dapat berbeda antara satu masyarakat dan masyarakat yang lain serta waktu dan waktu yang lain. ${ }^{22}$

Kemudian Allah menjelaskan bahwa rezeki itu berubah dari kesulitan menuju kelonggaran, dan sebaliknya. Firman-Nya:

$$
\text { فَاْنَّ مَعَع الْعُسنرِ يُسْرِا }
$$

Artinya : Allah akan menjadikan sesudah kesulitan itu kemudahan" (QS. QS. Alam Nasyroh: 5)

Sesudah kesempitan itu kelapangan dan sesudah kefakiran itu kekayaan. Sebab, dunia itu tidak tetap dalam suatu keadaan, sebagaimana dalam Firman-Nya:

22 M. Quraish Shihab, Tafsir Al-Mishbah, (Jakarta: Lentera Hati, 2002), hlm. 145-146. 


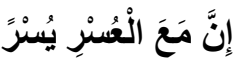

Artinya: "Sesungguhnya
sesudah kesulitan itu ada kemudahan.” (Q.S AlInsyirah, 94: 6). Kesemuanya itu merupakan berita gembira bagi orang-orang mukmin yang dikuasai kefakiran dan kepapaan. ${ }^{23}$

Pengaturan mengenai kadar nafkah yang harus dipenuhi oleh seorang suami atau ayah, baik dalam Al-Qur'an maupun dalam Al-Hadits, tidak pernah disebutkan secara tegas mengenai kadar atau jumlah nafkah yang wajib diberikan, begitu juga kepada anak-anak terlantar. Al-qur'an dan Al-hadis hanya menberikan gambaran umum saja.

1. DR. Yusuf Qordhawi

Dr. Yusuf Qordhawi mengatakan "Sangat disesalkan bahwa masih banyak ditemukan sikap suami yang tidak baik dalam cara memberikan nafkah kepada istrinya. Terdapat dua sikap yang bertentangan. Pertama, ada suami yang memberikan keluasan kepada istrinya dengan seluas-luasnya untuk berbuat tabdzir (konsumerisme), menghamburkan harta, dan berbelanja sekehendak hatinya, baik yang ada manfaatnya maupun tidak, yang diperlukan maupun tidak. secara gila-gilaan sang isteri berlomba-lomba dalam membeli pakaian. Mereka meniru mode Eropa atau Amerika dengan tidak memperhatikan kepentingan keluarga, tanah air dan bangsanya, serta tidak memikirkan kemungkinan-kemungkinan yang akan terjadi hari esok. Kedua, sebaliknya, yaitu ada juga suami-

23 Ahmad Mustafa Al-Maragi, Tafsir Al-Maragi, Jus 2, (Semarang: Cv Toha Putra, 1992), hal. 239. suami yang kikir dan pelit terhadap isterinya, membelenggu lehernya, tidak memberinya belanja yang mencukupi dan dapat memenuhi kebutuhankebutuhannya yang logis. Padahal, Allah dalam kitabNya mewajibkan sikap tengahtengah antara israf (berlebihan) dan pelit dalam belanja. ${ }^{24}$

2. DR. Wahbah Zuhaily

$$
\text { Wahbah zuhaili }
$$

menjelaskan bahwa yang dimaksud dengan nafkah istri itu adalah sebagai berikut ${ }^{25}$ : a) Makan dan minum serta lauk pauknya, b) Pakaian, c) Tempat tinggal, d) Furniture rumah, e) Pembantu, f) Alat-alat kebersihan dan perabotan rumah lainnya.

Kewajiban memberi nafkah ini dilakukan dengan cara yang baik. Adapun penjelasan tentang nafkah ini adalah sebagai berikut :

a. Makan. Wahbah zuhaili sependapat mengenai nilai nafkah istri sama seperti pendapat syafi'iyah yang mengatakan bahwa nafkah itu sesuai kemampuan seorang suami. Hal ini dilihat apakah suami sedang lapang atau sedang sulit. Jika sedang lapang maka suami memberi nafkah dengan kemampuannya. Begitu juga sebaliknya jika suami sedang sulit maka sesuai kemampuannya.

b. Pakaian. Sama halnya dengan kewajiban suami memberi

24 Yusuf Qardhawi, Hadyu al-Islàm Fatāwā Mu'àsirah, Juz 2, (Beirut: Dār al-Ma'rifah, 1988), hal. 166-167.

25 Wahbah Zuhaily, Fiqh Al-Islam Wa Adillatuhu, (Beirut : Daar Fikr, 1985, hal. 766 
nafkah makanan, pakain juga harus disesuaikan dengan kondisi saat itu. Pada tempat yang terdapat dua musim seperti musim panas dan musim dingin, maka suami wajib memberikan pakaian musim panas dan musim panas.

c. Tempat tinggal. Adapun batasan tempat tinggal yang dimaksud adalah tempat tinggal yang layak tanpa melihat apakah dengan cara menyewa atau dengan cara kepemilikan.

d. Pembantu. Jika seorang suami mempunyai kesanggupan maka ia wajib menyiapkan pembantu untuk istrinya dan jika tidak sanggup maka semampunya istrinya menyelesakan pekerjaan rumah sendiri.

Peralatan kebersihan dan perabotan rumah tangga. Mengenai hal ini Wahbah zuhaili sependapat dengan syafi'iah yang mengatakan kewajiban yang dimaksud adalah seperti sisir, sabun, dan air. Sedangkan untuk untuk perabotan rumah meliputi peralatan makan dan minum lengkap dengan peralatan masaknya. Adapun seperti peralatan kecantikan lainnya ukurannya hanya sekedarnya saja. Seperti wangiwangian tidak lebih hanya untuk menghilangkan bau badan. ${ }^{26}$ Selain kewajiban tersebut seorang suami juga harus menanggung perobatan istri.

D. Penyebab Terjadinya Perbedaan Pendapat Antara Ulama Klasik dan Kontemporer

Tidak ada nash yang jelas baik dari al quran maupun hadist yang

26 Wahbah zuhaili figh islam wa adillatuhu hal. 801-808. menjelaskan tentang nilai nafkah istri. Namun secara garis besar ulama klasik berbeda pendapat kepada dua pendapat. Pertama jumhur ulama yaitu hanafiyah, malikiyah dan hanabilah sepakat bahwa nilai nafkah berdasarkan kebutuhan istri menurut urf kebiasaan ditempat tersebut. Kedua syafi'iyah mengatakan berdasarkan kemampuan seorang suami. Jika suaminya seorang yang kaya maka nafkah yang diberikan 2 mud, jika dalam kondisi sulit ekonomi maka dengan 1 mud saja. Sedangkan jika kondisi pertengahan maka dengan nafkah pertengahan saja. Adapun sebab terjadinya perbedaan pendapat diantara mereka karena cara penafsiran ayat dan hadist yang berbeda. Seperti dalil yang mereka pakai dari QS. At-talaq ayat 7 yaitu:

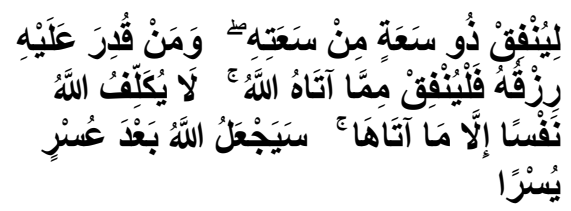

Artinya: Hendaklah orang yang mampu memberi nafkah menurut kemampuannya. Dan orang yang disempitkan rezekinya hendaklah memberi nafkah dari harta yang diberikan Allah kepadanya. Allah tidak memikulkan beban kepada seseorang melainkan sekedar apa yang Allah berikan kepadanya. Allah kelak akan memberikan kelapangan sesudah kesempitan.

Dalam memahami ayat diatas para ulama berbeda pendapat pada penafsiran kalimat ' infaq' . Jumhur menafsirkan kata infaq pemberian nafkah secukupnya tanpa membatasi ukurannya seperti halnya Allah memberi rezki kepada hambanya meskipun tidak ada ukurannya tapi 
menurut kebiasaan pasti cukup. Sementara syafi'iyah menafsirkan kata infaq pada ayat tersebut seperti halnya berinfaq. Bahwa Allah SW'T mewajibkan untuk berinfaq kepada hambanya tapi tetap saja tergantung pada kemampuan hambanya. Namun demikian harus diberikan ukuran yang jelas dan menurut adat kebiasaan sudah dinilai cukup.

Sebab perbedaan mereka yang selanjutnya adalah perbedaan hadist yang mereka pakai. Jumhur memakai hadist yang diriwayatkan oleh Aisyah ra.

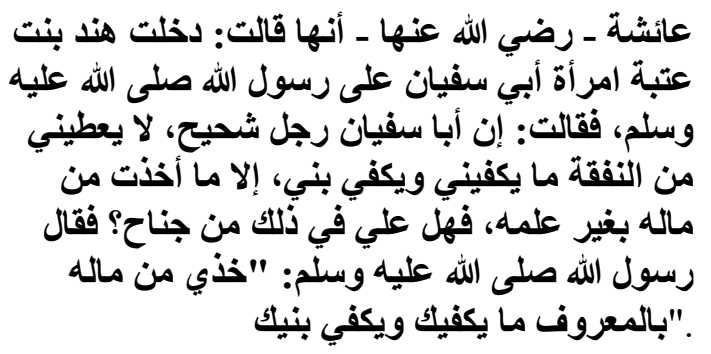

Artinya : dari Aisyah, bahwa Hindun bin Utbah istri Abi Sufyan pernah berkata kepada Rasulullah; "Sesungguhnya Abu Sufyan adalah seorang lelaki yang kikir, dia tidak memberiku dan anakku sesuatu yang mencukupi kami kecuali apa yang aku ambil dari hartanya tanpa sepengetahuannya!." Apakah saya termasuk orang yang berdosa? Kemudian Beliau bersabda: "Ambillah secukupnya untuk kamu dan anakmu dengan cara yang baik.

Jumhur ulama mengambil dalil dari hadist diatas dengan menfokuskan pada kalimat 'ma yakfika'. Artinya secukupnya. Dengan mengatakan bahwa infaq itu tergantung cukup atau tidaknya tanpa harus dibatasi.

Kemudian syafi'iyah
mengambil dari hadist yang

diriwayatkan oleh ka'ab bin 'uzrah yang menceritakan tentang kaffarah (sangsi) yaitu dengan berpuasa tiga hari jika tidak sanggup maka dengan memberikan makanan. Dari sinilah syafi'iyah berpendapat bahwa harus ada ukuran khusus untuk nafkah istri.

Adapun ulama kontemporer sesungguhnya tidak menyangkal pendapat para ulama klasik tentang ukuran nafkah ini. Namun ulama kontemporer seperti DR. Yusuf Qordhawi dan DR. Wahbah AlJuhaili hanya menambahkan jenis yang tergolong nafkah istri yaitu biaya berobat. Ulama kontemporer berijtihad bahwa biaya berobat juga termasuk salah satu bagian dari nafkah istri yang harus ditunaikan oleh seorang suami. Pada saat ini Polusi udara, makanan yang tidak sehat dan berbagai macam lainnya menjadi penyebab orang sering sakit dan berobat. Sehingga berobat saat sekarang ini berobat merupakan kebutuhan yang menjadi wajib. Wahbah al-Juhaily mengatakan seorang istri yang awalnya kita menikah dengannya dalam keadaan sehat maka bagaimana mungkin ketika dia sakit kita kembalikan ke orang tuanya. Hal tersebut benarbenar melanggar perintah Allah untuk memperlakukan istri dengan baik. Wa asyiruhunna bil ma'ruf.

Ulama klasik berbeda pendapat tentang ukuran atau kadar nafkah yang akan diberikan kepada istri. Pendapat pertama: Jumhur ulama yaitu Hanafiah $^{27}$, Malikiah ${ }^{28}$,

27 Al-Haskafy, Durrul Mukhtar, (Beirut : Daar Al-Kutub Al-Alamiyah, 2002), hal. 259

28 Ad-Dusuqy, Hasyiah Ad-Dusuqy 'Ala Syarh Al-Kabir, (Berut : Daar Ihya Kutub Al-Arobiyah, tt) :, hal. 509 
dan Hanabilah ${ }^{29}$ mengatakan bahwa ukuran nafkah yang akan diberikan adalah sesuai kebutuhan istri. Namun demikian Abu Hanifah berpendapat bahwa istri wajib diberikan nafkah oleh suami sebesar tujuh sampai delapan dirham setiap bulan, sedang orang yang pendapatannya kecil wajib memberikan nafkah dibawah tujuh dirham yaitu empat sampai lima dirham. ${ }^{30}$

Pendapat kedua : Ulama Syafi'iah $^{31}$ berpendapat sebaliknya yaitu dengan takaran yang sudah ditentukan. Namun demikian ukurannya akan dilihat dari kemampuan seorang suami. Jika seorang suami dalam kondisi mudah maka wajib memberikan 2 mud (1.350 gram gandum/beras), jika dalam kondisi sulit 1 mud (1012,5 gram) dan jika dalam kondisi stabil yaitu antara kondisi mudah dan sulit maka wajib memberikan nafkah istri sebanyak 1,5 mud (675 gram) ${ }^{32}$.

Ulama kontemporer seperti DR. Yusuf Qordhawi dan DR. Wahbah AlJuhaili hanya menambahkan jenis yang tergolong nafkah istri yaitu biaya berobat. Ulama kontemporer berijtihad bahwa biaya berobat juga termasuk salah satu bagian dari nafkah istri yang harus ditunaikan oleh seorang suami. Pada saat ini Polusi udara, makanan yang tidak sehat dan berbagai macam lainnya menjadi penyebab orang sering sakit dan berobat. Sehingga berobat

29 Ibnu Quddamah, al-Mughny, (Beirut : Daar al-fikri, tt) Jil. 11, hal.202

30 Yusuf Qarḍhawi, Fatwa-Fatwa Kontemporer, Jilid 1, Terjemah, As'ad Yasin, (Jakarta: Gema Insani Press, 2008), hlm. 679.

31 Taqiyuddin, Kifayat Al-Akhyar, (Damaskus : Daar Al-Basyair, 2001), hal. 526

32 Al-Imam Abi Abdullah Muhammad bin Idris al-Syafi'i, Al-Umm, Juz V, (Beirut: Dar al-Kutub al-Ilmiyah, tth), hlm. 95 saat sekarang ini berobat merupakan kebutuhan yang menjadi wajib. Wahbah al-Juhaily mengatakan seorang istri yang awalnya kita menikah dengannya dalam keadaan sehat maka bagaimana mungkin ketika dia sakit kita kembalikan ke orang tuanya. Hal tersebut benar-benar melanggar perintah Allah untuk memperlakukan istri dengan baik.

\section{Kesimpulan}

Dari berbagai pendapat para ulama tentang nilai nafkah istri, pada dasarnya kebutuhan pokok manusia adalah sama yaitu pangan, sandang, dan papan. Akan tetapi seiring dengan kemajuan zaman, prioritas kebutuhan manusia memiliki jenjang tertentu sesuai dengan taraf hidup masing-masing. Jumhur ulama yaitu Hanafiah, Malikiah, dan Hanabilah mengatakan bahwa ukuran nafkah yang akan diberikan adalah sesuai kebutuhan istri. Sementara Ulama Syafi'iah berpendapat nilai nafkah diberikan dengan takaran tertentu yang melihat kondisi suami. Adapun ulama kontemporer seperti DR. Yusuf Qordhawi dan DR. Wahbah Al-Juhaili hanya menambahkan jenis yang tergolong nafkah istri yaitu biaya berobat. Ulama kontemporer berijtihad bahwa biaya berobat juga termasuk salah satu bagian dari nafkah istri yang harus ditunaikan oleh seorang suami.

Peneliti selanjutnya agar mencari ulama-ulama kontemporer lainnya untuk menambah khazanah keilmuan, khususnya bab mengenai nafkah ini.

\section{Daftar Pustaka}

Abdillah, Kudrat, Maylissabet, M. Taufiq, Kontribusi Babtsul Masail Pesantren di Madura dalam Menghadapi Perkembangan Hukum Islam

Abdul Rahman, Fiqh Munakahat, Cet. 1 (Jakarta: Kencana, 2003) 
Ad-Dusuqy, Hasyiah Ad-Dusuqy 'Ala Syarh Al-Kabir, (Berut : Daar Ihya Kutub Al-Arobiyah, tt)

Ahmad Mustafa Al-Maragi, Tafsir AlMaragi, Jus 2, (Semarang: Cv Toha Putra, 1992)

Ahmad Rofiq, Hukum Islam di Indonesia, (Jakarta: PT. Raja Grafindo Persada, 1997)

Al-Haskafy, Durrul Mukhtar, (Beirut : Daar Al-Kutub Al-Alamiyah, 2002)

Al-Imam Abi Abdullah Muhammad bin Idris al-Syafi'i, Al-Umm, Juz V, (Beirut: Dar al-Kutub)

Al-Imam Asy-Syafi'i, Al-Umm (Kitab Induk), Terjemahan Tk. H. Ismail Yakub, Jilid 7 (Kuala Lumpur: Victory Agencie, $\mathrm{tt}$ )

Al-Juzairi. Fikih 4 mazhab. Jilid 4, (Maktabah Taufikiyah Kairo, tt). Hal 536.

al-Ma'rifah, 1988)

Al-Qahdi Abu Syujae Bin Ahmad AlIshfahani, Ringkasan Fiqih Mazhab Syafie $i$ Penjelasan Kitab Matan Abu Syujae Dengan Dalil Al-Quran Dan Hadits, Terj. Toto Edidarmo, (Jakarta: Noura Books, 2012)

Amir Syarifuddin, Hukum Islam di Indonesia, Cet. 2 Jakarta: Kencana, 2007)

Depag RI, Al-Qur'an dan Terjemahnya, (Surabaya: Surya Cipta Aksara, 1993)

Gema Insani Press, 2008)

Ibnu Quddamah, al-Mughny, (Beirut : Daar al-fikri, tt)

Jasir Judah 'Ali Al”'Asy, Nafaqob Jauriyah, (Gaza: Kulliyah Syari'ah Wal Qanun, 2007)

M. Quraish Shihab, Tafsir Al-Mishbah, (Jakarta: Lentera Hati, 2002),
Mahmud Yunus, Hukum Perkawinan Dalam Islam, (Jakarta: CV. AlHidayah, 1968).

Sayyid Sabiq, Fiqh al-Sunnah, Juz II, (Kairo: Maktabah Dar al-Turas, tth)

Sayyid Sabiq, Fiqih Sunnah, Terj. Nor Hasanuddin, jlid 3, Jakarta Selatan: Pena Pundi Aksara, 2006)

Syaikh Hasan Ayyub, Fikih Kelurga, Terj. M. Abdul Ghoffar, (Jakarta Timur: Pustaka Al-Kausar, 1999)

Taqiyuddin, Kifayat Al-Akhyar, (Damaskus : Daar Al-Basyair, 2001)

Taufiq, M, Optimalisasi Peran Dewan Pengawas Syariah di Lembaga Keuangan Mikero Syariah, Al Huquq : Journal of Indonesian Islamic Economic Law, 2020.

Taufiq, M., dan Muklisin Purnomo, Model Pemberdayaan Aset Wakaf Masjid Secara Produktif Di Masjid Jogokariyan Yogyakarta, Jurnal Perada: Jurnal Studi Islam Kawasan Melayu, 2018.

Wahbah Zuhaili, Fiqh Imam Syafi'i, Jilid 3,Terj. Muhammad Afifi, abdul Hafiz (Jakarta: Almahira, 2010),

Wahbah Zuhaily, Figh Al-Islam Wa Adillatuhu, (Beirut : Daar Fikr, 1985)

Yusuf Qarḍhawi, Fatwa-Fatwa Kontemporer, Jilid 1, Terjemah, As'ad Yasin, (Jakarta: Gema Insani Press, 2008)

Yusuf Qardhawi, Hadyu al-Islām Fatāwā Mu'àsirah, Juz 2, (Beirut: Dār alMa'rifah, 1988)

Zakiah Daradjat, Ilmu Fiqih, jilid II, (Yogyakarta: PT.Dana Bhakti Waqaf, 1995) 